\title{
Clinical phenotype and karyotype finding of Turner syndrome in Jakarta
}

\author{
I Nyoman Arie Purwana ${ }^{1 *}$, I Made Arimbawa², Frida Soesanti', Aman B Pulungan'1', Jose RL Batubara' \\ From 7th APPES Biennial Scientific Meeting \\ Nusa Dua, Bali. 14-17 November 2012
}

Turner syndrome (TS) is the most common sex chromosome abnormality of female, occurs in one in 2500 live-born females. TS combines' characteristic physical features with complete or partial absence of the X chromosomes, frequently accompanied by cell mosaicsm. Endocrinology 2013 2013(Suppl 1):P57. The aims of this study is to describe the clinical phenotype and karyotype of patient with Turner Syndrome in Jakarta, Indonesia.

Data was collected from medical records of the Pediatrics Endocrinology Clinic, Cipto Mangunkusumo Hospital in Jakarta since 2000-2012.

Of the 23 cases collected, the mean age at diagnosis was 7.75 years (range $0-15$ years). The most common problem that bring patients came to the clinic were short stature (69.6\%) and delayed puberty (30.4\%). There were 8 patients with concomitant disorders: 4 cardiac abnormalities, 3 with ear disorders, 1 with hypertension. From16 patients who had bone age evaluation, 11 patients showed retarded age. A total of 17 patients had a karyotype $45, \mathrm{X}$ and the rest are mosaics.

Our study suggest that the main characteristics of Turner syndrome is a karyotype 45,X with the physical characteristics of short stature and delayed puberty.

\section{Authors' details}

'Department of Pediatrics Endocrinology Cipto Mangunkusumo Hospital, Jakarta, Indonesia. ${ }^{2}$ Department of Pediatrics Endocrinology Sanglah Hospital, Denpasar, Indonesia.

Published: 3 October 2013

'Department of Pediatrics Endocrinology Cipto Mangunkusumo Hospital, Jakarta, Indonesia

Full list of author information is available at the end of the article

Submit your next manuscript to BioMed Central and take full advantage of:

- Convenient online submission

- Thorough peer review

- No space constraints or color figure charges

- Immediate publication on acceptance

- Inclusion in PubMed, CAS, Scopus and Google Scholar

- Research which is freely available for redistribution

Submit your manuscript at www.biomedcentral.com/submit
() Biomed Central 